\title{
Local content requirements, vertical cooperation, and foreign direct investment
}

Citation for published version (APA):

Jie-A-Joen, C., Belderbos, R. A., \& Sleuwaegen, L. (1998). Local content requirements, vertical cooperation, and foreign direct investment. NIBOR, Netherlands Institute of Business Organization and Strategy Research. NIBOR Research Memorandum No. 01 https://doi.org/10.26481/umanib.1998001

Document status and date:

Published: 01/01/1998

DOI:

10.26481/umanib.1998001

Document Version:

Publisher's PDF, also known as Version of record

\section{Please check the document version of this publication:}

- A submitted manuscript is the version of the article upon submission and before peer-review. There can be important differences between the submitted version and the official published version of record.

People interested in the research are advised to contact the author for the final version of the publication, or visit the DOI to the publisher's website.

- The final author version and the galley proof are versions of the publication after peer review.

- The final published version features the final layout of the paper including the volume, issue and page numbers.

Link to publication

\footnotetext{
General rights rights.

- You may freely distribute the URL identifying the publication in the public portal. please follow below link for the End User Agreement:

www.umlib.nl/taverne-license

Take down policy

If you believe that this document breaches copyright please contact us at:

repository@maastrichtuniversity.nl

providing details and we will investigate your claim.
}

Copyright and moral rights for the publications made accessible in the public portal are retained by the authors and/or other copyright owners and it is a condition of accessing publications that users recognise and abide by the legal requirements associated with these

- Users may download and print one copy of any publication from the public portal for the purpose of private study or research.

- You may not further distribute the material or use it for any profit-making activity or commercial gain

If the publication is distributed under the terms of Article $25 \mathrm{fa}$ of the Dutch Copyright Act, indicated by the "Taverne" license above, 


\title{
LOCAL CONTENT REQUIREMENTS, VERTICAL COOPERATION, AND FOREIGN DIRECT INVESTMENT*
}

\author{
Clive Jie-A-Joen \\ Arthur Andersen \\ René Belderbos \\ Maastricht University \\ Leo Sleuwaegen \\ Catholic University of Leuven and Erasmus University Rotterdam
}

NIBOR/RM/98/01

Faculty of Economics and Business Administration

\author{
NIBOR (Netherlands Institute of Business Organization and Strategy Research) \\ Maastricht University \\ Department of Management Science \\ P.O. Box 616 \\ 6200 MD Maastricht \\ The Netherlands \\ Telephone: +31433883806 \\ Facsimile: +31433258495 \\ Email: r.belderbos@mw.unimaas.nl
}

\footnotetext{
* The order of authors is a variation on previous citations and does not reflect unequal contributions. We thank Arjen van Witteloostuijn and participants at the EARIE conference and seminars at the Université Paris I (Sorbonne-Panthéon) and Erasmus University Rotterdam for helpful comments. All remaining errors are our own. Clive Jie-A-Joen gratefully acknowledges support by the Tinbergen Institute at Erasmus University Rotterdam and René Belderbos wishes to thank the Science Policy Research Unit at the University of Sussex for its support.
} 


\title{
LOCAL CONTENT REQUIREMENTS, VERTICAL COOPERATION, AND FOREIGN DIRECT INVESTMENT
}

\author{
Keywords: \\ Local content requirements, cooperative bargaining; foreign direct investment
}

JEL Codes:

F13, F23, L13, L22

\begin{abstract}
We examine the effects of a local content requirement (LCR) in the context of potential vertical cooperation between a host country's upstream and downstream producers and foreign direct investment (FDI) in upstream manufacturing by a foreign multinational. The relationship- specific investment which sustains cooperation also allows the host country firms to commit to a FDI preempting strategy through manipulation of the price of intermediates supplied to the foreign firm. It is found that depending on the presence of economies of scale in the upstream industry and the cost advantage of the multinational, the LCR can either induce cooperation and increase host country profits, or reduce the incentives to cooperate and induce FDI. In the latter case, the LCR reduces profits of all firms but benefits consumers.
\end{abstract}




\section{Introduction}

There is now an extensive body of literature analysing the welfare and resource allocation effects of local content requirements (LCRs). Early work was inspired by the frequent use of LCRs in less developed countries and focused on the resource-allocating effects of LCRs aimed at developing the local intermediate goods industry [Corden (1971), Grossman (1981), Dixit and Grossman (1982), Mussa (1984), Vousden (1987)]. These studies typically assumed perfectly competitive industries, although the case of intermediate goods monopoly has also received attention. Krishna and Itoh (1988) extended this line of work by examining the effects of LCRs in case of an oligopolistic intermediate goods industry. Recent work has adopted a general equilibrium approach to analyse the welfare effects of LCRs under sector-specific unemployment [Chao and Yu (1993)], and with variable labor supply [Fung (1994)].

The use of LCRs in industrialised countries has given rise to another line of research focusing on the strategic rent shifting effects of LCRs in imperfectly competitive industries [Davidson et al. (1987), Richardson (1991), Lopes-de-Silanes et al. (1996), Belderbos and Sleuwaegen (1997)]. The growing importance of rules of origin with the creation of regional trade blocs such as the North American Free Trade Association (NAFTA) provides an example of such LCRs. Rules of origin are often designed to target the less integrated manufacturing operations of foreign-owned firms in oligopolistic industries. They aim to enhance the competitive position of domestic final goods producers by forcing similar procurement conditions on to foreign firms. The NAFTA rule of origin for automobiles, for examples, implies that cars assembled in NAFTA countries can only be traded duty-free within the region if at least 62.5 percent of value added is generated within the trade bloc. This rule de facto affected the operations of Japanese firms in a discriminatory way. Lopes-de Silanes et al. (1996) analyzed the anti-competitive and rent shifting effects of a LCR in conjunction with a voluntary export restraint (VER) using a calibrated general-equilibrium model of the North American auto industry. Earlier work by Davidson et al. (1987) focused on the cost increasing effects of LCRs when the final goods industry is a duopoly of a domestic firm and a foreign assembler, but did not consider repercussions on the intermediate goods market. Richardson (1991) took a similar duopoly setup but endowed the duopolists with market power on a perfectly competitive intermediate goods market. Belderbos and Sleuwaegen (1997) examined the case of successive market power in intermediate goods and final goods industries. The latter study took its 
inspiration from LCRs embodied in an anti-circumvention clause in the European Union's antidumping law, which targeted Japanese firms assembling electronics products in Europe. A central result of these studies is that LCRs can have anti-competitive output reducing effects, while both domestic welfare and profits of domestic final goods producers can be negatively affected. This is because the LCR increases demand for intermediate goods and pushes up intermediate goods prices, which negatively affects domestic final goods producers. In Richardson (1991) and Lopesde-Silanes et al. (1996) this price increase stems from increased factor costs in a competitive intermediate goods industry, while in Belderbos and Sleuwaegen (1997) the price increase stems from increased market power of an oligopolistic intermediate goods industry. Beghin and Sumner (1992) have recently shown that the output reducing effects of LCRs can be avoided in case of cooperative bargaining between the final goods and intermediate goods industries. They found in a bilateral monopoly setting that -even non-binding- LCRs will shift profits from the final goods industry to the intermediate goods industry without affecting output or final goods prices. Beghin and Knox Lovell (1993) showed that the cooperative bargaining model can be applied to the Australian tobacco and tobacco leaf industries, where LCRs have been present and vertical cooperation has been supported by the government.

As diverse as the literature on LCRs has become, two issues of empirical relevance have still been largely ignored. First, the possibility of foreign direct investment (FDI) in local intermediates production by the foreign firms as a response to the imposition of LCRs has not received due attention. There is abundant evidence, both in the US car industry and the EU electronics industry, that Japanese firms responded by further integrating their overseas production or arrange for intermediate goods suppliers in the vertical business group (keiretsu) to set up plants abroad [e.g. Belderbos (1997, chapter 2)]. Two studies of LCRs have taken FDI into account but are not readily applicable to LCR-induced FDI in oligopolistic car and electronics industries. Hollander (1987) considered welfare effects of a foreign multinational responding to a LCR by shifting more production stages to the host country, and found that small LCRs can increase welfare. Richardson (1993) extended the analysis of LCRs to include international capital flows in the intermediate goods sector. In a general equilibrium framework under perfect competition and constant returns to scale, he obtained that LCRs no longer affect the price of the intermediate good. 
A second and related issue is vertical cooperation or vertical integration between domestic firms in a strategic rent shifting framework. The literature on rent shifting LCRs has consistently assumed that the domestic intermediate goods industry sells on arm's length markets to the final goods industry. ${ }^{1}$ The foreign final goods producers are treated as vertically integrated and reliant on imports of intermediates from related foreign plants, which provides the rationale for the imposition of the LCR in the first place. Once domestic firms are able to cooperate or vertically integrate, the LCR may allow strategic pricing of the intermediate good for sale to the foreign firms in order to reap additional profits on the final goods market. Vertical foreclosure of the foreign firm is a possibility, but the foreign firm is likely to respond by setting up its own intermediate goods plant in the LCR imposing country. ${ }^{2}$

There is one well documented example of LCRs and vertical integration by domestic firms: color televisions and colour television tubes in the European Union. In the 1970s, a range of import barriers for Japanese televisions as well as restrictive licensing policies for European PAL broadcasting technology, prompted all major Japanese television manufacturers to invest in European production facilities. Most of the plants were set up in the United Kingdom, at the time the largest European market for televisions. The Japanese firms had an apparent preference for the use of components from Japan, but their European manufacturing operations have been subject to a number of LCRs. A 45 percent of value added criterion applied until 1992 in case the UK-produced televisions were to be exported duty free to France, Spain, and Italy, ${ }^{3}$ and the Japanese firms reportedly had to agree with a request from the UK government to attain a 70 percent local content ratio [Burton and Saelens (1987)]. ${ }^{4}$ To satisfy these requirements, local sourcing of television tubes, which can make up 40 percent of the value of a television, became a necessity. Television tubes in Europe, however, were until recently only produced by the three vertically integrated European

\footnotetext{
${ }^{1}$ Belderbos and Sleuwaegen (1997) briefly discuss the consequences of vertical cooperation between domestic intermediate goods and final goods producers.

${ }^{2}$ This situation has broad similarities with the vertical foreclosure models developed in Spencer and Jones (1991, 1992) and Rodrik and Yoon (1989). These models consider the impact of host country trade policies on the supply of intermediate goods by a vertically integrated foreign firm to domestic final goods producers. In case the foreign firm decides to vertically foreclose the host country firms, the latter may set up their own local intermediate goods production.

${ }^{3}$ France, Italy, and Spain maintained strict national quota for Japanese television imports and in practice UKproduced televisions were counted in the quota if they did not satisfy the EC's rules of origin for color televisions [Belderbos (1997, chapter 1)].

${ }^{4}$ In addition, Japanese firms reportedly promised to limit exports of television tubes to the EC in a 1982 agreement between the EC Commission and Japan's Ministry of International Trade and Industry [Tyson (1992, Chapter 6)]. The EC also maintains a 15 percent tariff on tube imports, providing further incentives for local procurement of tubes.
} 
television producers: Philips of the Netherlands, Thomson of France, and Nokia of Finland. Major Japanese producers such as Matsushita (maker of the Panasonic and Quasar brands), Hitachi, and Sanyo have since the 1970s bought tubes for their European operations from these European firms. ${ }^{5}$ In contrast, Japanese firms have set up several production facilities for a number of other television parts such as tuners, power sources, and plastic moldings. The high plant setup cost and the substantial economies of scale in television tube production made FDI a less cost-effective option, in particular given the initial small scale of Japanese firms' EU manufacturing operations. The only Japanese firm which set up its own European tube plant in the 1980s was Sony. Sony uses a proprietary tube standard and is by far the largest Japanese television producer in Europe.

The objective of this paper is to examine the effects of LCRs in the context of vertical cooperation between domestic firms and FDI by foreign firms. A model is developed which extends the cooperative bargaining analysis of Beghin and Sumner (1992) to a strategic rent shifting framework with imperfect competition. While designed to encompass the EU television case, the model has a broader setup and allows for vertical cooperation between host firms to arise as an equilibrium outcome. The setup is simple, with a domestic monopolist supplying intermediates to a domestic final goods producer and a foreign multinational (in case of a LCR). A LCR hits the multinational in a discriminatory way since it prefers to imports all intermediates from its own plant abroad in the absence of such a requirement. The imposition of the LCR can under certain circumstances increase the likelihood that the domestic firms choose for vertical cooperation. In this case they find it beneficial to set the price of the intermediate for sale to the foreign multinational such that the latter firm finds local sourcing from the domestic firms more cost-effective than FDI. The potential of such a 'FDI pre-empting' strategy depends crucially on the presence of a cost advantage of the foreign firm and the degree of scale economies in intermediate goods production. The welfare effects of LCRs in case of potential vertical cooperation and FDI are generally more likely to be positive than in the absence of these possibilities.

\footnotetext{
${ }^{5}$ See Belderbos (1997, Chapters 1 and 4) and "TV maker sees end to a local difficulty", Financial Times, 18 March 1994. Recently, Samsung of Korea has set up a tube plant in Germany and in December 1994 Matsushita acquired Nokia's two German tube plants ("Matsushita Acquires Nokia Tube Factory", Financial Times, 1 December 1994).
} 
The analysis also links up with the recent game theoretical literature on strategic foreign direct investment. ${ }^{6}$ Although this literature has paid attention to the effects of trade policies, it has not examined the vertical relationship with the intermediate goods industry. ${ }^{7}$ The present paper extends this literature by introducing the notion that vertical cooperation between domestic firms can facilitate the pre-emption of FDI and hence has a special strategic significance. It models a game in which the domestic firms act as leader and decide on cooperation after which the foreign firm chooses between FDI and local sourcing. The equilibrium outcomes of this game are examined under alternative values of the LCR and different cost configurations.

The remainder of this paper is organized as follows. The next section presents the main assumptions of model and establishes conditions under which the different outcomes occur. Section 3 examines the effects of a LCR on the domestic firms' decision to cooperate and the foreign firm's choice between local sourcing and FDI. Section 4 examines the welfare implications and Section 5 concludes.

\section{The Model}

Consider two downstream firms, labeled $\mathrm{d}$ (domestic or downstream) and $\mathrm{f}$ (foreign), assembling identical final goods in a host country and selling these on the host country market. Nash-Cournot equilibrium prevails on the final goods market. The inverse demand function for the final good is $P=1-\left(q^{d}-q^{f}\right) / s$, where s measures the size of the host country market, and $q^{d}$ and $q^{f}$ represent the output of firm $\mathrm{d}$ and firm f, respectively. The production technology is such that one unit of labour and one unit of the intermediate good are needed to produce one unit of the final good. The firms are price-takers in the labour market at unit wage $w$ which, without loss of generality, is set to zero. The domestic downstream firm procures intermediates from a domestic upstream firm, labeled $\mathrm{u}$ (upstream), which produces at constant marginal cost $c^{u}$. The domestic firms may consider to vertically cooperate by entering into Nash bargaining to determine price and volume of the intermediate good. Following the stylized facts of the European color television case,

${ }^{6}$ e.g. Smith (1987), Dei (1990), Motta (1992), Cordella and Vannini (1995), Sanna-Randaccio (1996) and Motta and Norman (1996). 
the foreign multinational at the outset imports all intermediate goods from its plant abroad. This preference for imports may be based on a marginal cost advantage in serving the European market: firm $\mathrm{f}$ is assumed to produce intermediates abroad at constant marginal cost $c^{f}$, while $c^{f}+t \leq c^{u}$, where $t$ are unit transport and tariff costs. The intermediate goods produced by firms $u$ and $f$ are assumed to be perfect substitutes.

The host country government now imposes a LCR which requires that final goods producers procure at least a certain specified proportion $\varepsilon \quad(0<\varepsilon \leq 1)$ of the intermediate goods it needs for final goods assembly in the host country. ${ }^{8}$ The foreign firm then faces the choice between procuring the required share of intermediates from firm $\mathrm{u}$, and setting up its own intermediate goods plant in the host country. In the latter case, a plant-specific fixed cost $G$ has to be incurred, but the unit transport and tariff cost $t$ is avoided and marginal costs are $c^{f} .{ }^{9}$

In order to examine the strategic effects of vertical cooperation we consider the following threestage game. In the first stage, firms $u$ and $d$ decide whether to vertically cooperate. The advantages of cooperation depend on the choice of firm $\mathrm{f}$ between local sourcing and FDI in the second stage of the game. Firms $\mathrm{u}$ and $\mathrm{d}$ move first and choose between cooperation and non-cooperation taking account of the best response of firm $\mathrm{f}$. In the third stage quantity competition takes place and the price of the intermediate good is determined. The equilibrium is subgame-perfect and solved backwards. Firms maximize the aggregate of variable profits minus fixed costs. Let $\Pi_{k}^{i}$ represent variable profits of firm $i$, with $i \in\{\mathrm{u}, \mathrm{d}, \mathrm{f}\}$. The subscript $k$ denotes the four possible outcomes of the game: NF (non-cooperation and FDI), CF (cooperation and FDI), NL (non-cooperation and local sourcing), and CL (cooperation and local sourcing). The various outcomes of the game involve different payoffs to the firms.

In case firms $\mathrm{u}$ and $\mathrm{d}$ do not cooperate, upstream firm $\mathrm{u}$ is assumed to be endowed with market power on the intermediate goods market while the downstream firms take the price of the

\footnotetext{
${ }^{7}$ Bughin and Vannini (1994) examined vertical effects, but focused on the influence of union-firm bargaining on FDI decisions.

${ }^{8}$ The LCR considered is a physical local content scheme appropriate in a setting of homogeneous intermediates. The early literature has also considered value added content protection schemes [Grossman (1981), Hollander (1987), and Krishna and Itoh (1988)].

${ }^{9}$ In other words, firm $\mathrm{f}$ is able to transfer its cost advantage to its plant abroad.
} 
intermediate as given. ${ }^{10}$ Vertical cooperation occurs if firms $\mathrm{u}$ and $\mathrm{d}$ can reach an agreement on a pair $\left(p^{d}, q^{d}\right)$, where $p^{d}$ denotes the price which firm u charges firm $\mathrm{d}$ for the intermediate good. Following Beghin and Sumner (1992), the generalized Nash cooperative bargaining game is used to approach the bargaining problem between the host firms (the description of this bargaining game is relegated to the appendix). If a cooperative solution is not reached, conflict payoffs are equal to profits under upstream leadership. Vertical cooperation has the advantage that it eliminates the mark-up on intra-group deliveries of intermediates, improving the competitive position of firm $\mathrm{d}$ on the final goods market. On the other hand, cooperation does involve costs. For instance, in order to deal with opportunistic behavior, the firms may have to set up an audit mechanism and incur monitoring costs. ${ }^{11}$ Cooperation will involve relationship-specific investments to express a mutual commitment to cooperation [Chung (1995)]. Irreversible investments which are specific to the vertical relationship cannot be utilized for other purposes in case the firms withdraw from the cooperative agreement. We let $F^{T}=F^{u}+F^{d}$ denote the fixed investment cost associated with cooperation (a superscript $\mathrm{T}$ denotes total cost) which is not necessarily evenly distributed among the two domestic firms.

In the cooperative bargaining framework, the decision to cooperate depends on the extent to which cooperation allows for an increase in joint variable profits. An individual firm cooperates if its share of this increase in profits (which depends on its bargaining power) is greater than the cost of cooperation it has to incur. The profit gain in case of cooperation not only stem from the efficiency advantage through the elimination of the internal mark-up, they also involve a strategic advantage. With the LCR imposed, cooperation allows for the strategic setting of the intermediate goods price $p^{f}$ charged to firm $\mathrm{f}$, while $p^{d}$ is determined in the internal bargaining process. ${ }^{12}$ The sunk cost $F^{T}$ has a commitment value which allows the domestic firms to credibly commit to such

\footnotetext{
${ }^{10}$ This price-taking assumption has been frequently used in the literature [e.g., Greenhut and Ohta (1978), Waterson (1982), Salinger (1988), and Sleuwaegen et. al (forthcoming)]. A leadership position of the upstream firm may stem from the imposition of the LCR which increases market power of upstream firms [Grossman (1981)], and from pre-committed investments in the technology and capacity to produce intermediates. It is also assumed that the cost of acquiring the technology to produce the intermediate goods precludes firm $\mathrm{d}$ from setting up it own production.

${ }^{11}$ The management literature identifies further potential costs of cooperation and coalitions: coordination costs, erosion of competitive position, and creation of an adverse bargaining position [Porter (1986], competitive compromise, dependency spiral, and distrust and conflict [Hamel et al. (1989)]. D'Aveni and Ravenscraft (1994) provide examples of the costs associated with vertical integration, and Williamson (1989) provides a general analysis of the governance costs associated with contractual relations.
} 
a pricing strategy. In the absence of the FDI option, the domestic firms would set $p^{f}$ high enough to induce the exit of firm $\mathrm{f}$ (vertical foreclosure). However, firm $\mathrm{f}$ can respond by investing in a local intermediate goods plant. Since local production reduces the marginal cost of firm $\mathrm{f}$ by a factor $t$, the FDI choice implies a detoriation of the relative cost position of the domestic firms which results in lower variable profits. ${ }^{13}$ Hence, the cooperating domestic firms have an incentive to set $p^{f}$ as high as possible but just below the FDI inducing level: we call this the 'FDI pre-empting' price. Cooperation in the context of an LCR has a strategic significance in that it allows for a FDI preempting strategy.

We can now describe the conditions under which any of the four possible outcomes of the game is the equilibrium outcome. Sufficient conditions for NL to be the equilibrium outcome are:

$$
\begin{aligned}
& \Pi_{N L}^{f}>\Pi_{N F}^{f}-G ; \\
& \Pi_{N L}^{T}>\Pi_{C L}^{T}-F^{j} / \gamma^{j} ; \\
& \Pi_{N L}^{T}>\Pi_{C F}^{T}-F^{j} / \gamma^{j} .
\end{aligned}
$$

Where a superscript $\mathrm{T}$ denotes the sum of variable profits of firms $\mathrm{u}$ and $\mathrm{d}, j \in\{\mathrm{u}, \mathrm{d}\}$, and the parameter $\gamma$ denotes bargaining power with $\gamma^{d}+\gamma^{u}=1$. Condition (1a) determines that firm $\mathrm{f}$ chooses local sourcing if the domestic firms choose not to cooperate, and conditions (1b) and (1c) establish that the domestic firms do not cooperate. Sufficient conditions for CL to be the equilibrium outcome are:

$$
\begin{aligned}
& \Pi_{C L}^{f}>\Pi_{C F}^{f}-G ; \\
& \Pi_{C L}^{T}>\Pi_{N L}^{T}+F^{j} / \gamma^{j} ; \\
& \Pi_{C L}^{T}>\Pi_{N F}^{T}+F^{j} / \gamma^{j} .
\end{aligned}
$$

\footnotetext{
${ }^{12}$ Such price discrimination does not work in case of non-cooperation since firms $\mathrm{d}$ and $\mathrm{f}$ will be able to practice arbitrage.

${ }^{13}$ A characteristic of FDI here is that it involves a transformation of variable cost into fixed cost. See Motta (1992) and Smith (1987) for a similar treatment of FDI.
} 
$\mathrm{NF}$ is the equilibrium outcome if:

$$
\begin{aligned}
& \Pi_{N F}^{f}-G>\Pi_{N L}^{f} ; \\
& \Pi_{N F}^{T}>\Pi_{C L}^{T}-F^{j} / \gamma^{j} ; \\
& \Pi_{N F}^{T}>\Pi_{C F}^{T}-F^{j} / \gamma^{j} .
\end{aligned}
$$

$\mathrm{CF}$ is the outcome if:

$$
\begin{aligned}
& \Pi_{C F}^{f}-G>\Pi_{C L}^{f} ; \\
& \Pi_{C F}^{T}>\Pi_{N F}^{T}+F^{j} / \gamma^{j} ; \\
& \Pi_{C F}^{T}>\Pi_{N L}^{T}+F^{j} / \gamma^{j} .
\end{aligned}
$$

Following the circumstances under which LCRs were imposed in the EU color television industry and in order to focus on the potential of the LCR to bring about shifts in equilibrium outcomes, it is assumed that in an initial equilibrium situation (characterized by the absence of a LCR) there is non-cooperation and firm $\mathrm{f}$ imports all intermediates from abroad. This situation is denoted by $\mathrm{NL}^{*}$ (an asterisk indicates the absence of the LCR). This implies that the following conditions hold:

$$
\begin{aligned}
& \Pi_{N F^{*}}^{f}-G<\Pi_{N L^{*}}^{f} ; \\
& \Pi_{C F^{*}}^{f}-G<\Pi_{C L^{*}}^{f} ; \\
& \Pi_{C L^{*}}^{T}<\Pi_{N L^{*}}^{T}+F^{j} / \gamma^{j} .
\end{aligned}
$$

Conditions 5a and 5b establish that FDI does not occur under free trade, and condition 5c establishes that if firm $\mathrm{f}$ chooses to rely on imports under free trade, cooperation is not chosen. 


\section{LCRs, FDI, and the Gains from Vertical Cooperation}

The introduction of the LCR affects both domestic firms' incentives to cooperate and the foreign firm's FDI decision. The effect of the LCR crucially depends on industry structure, in particular economies of scale, the cost advantage of firm $\mathrm{f}$ in intermediate goods production, the cost of cooperation, and the size of the market. We solve the three stage game by backward induction and examine the FDI decision by firm $\mathrm{f}$ first.

\subsection{FDI Versus Local Sourcing}

Foreign firm $\mathrm{f}$ chooses between FDI and local sourcing given that the host country firms have chosen non-cooperation or cooperation in the first stage of the game. At the final stage of the game, output levels are determined following Cournot-Nash equilibrium. We start with the situation in which the host country firms have chosen non-cooperation.

\section{Non-Cooperation}

In case of non-cooperation, firm u sells its intermediate goods to firms $\mathrm{d}$ and $\mathrm{f}$ at the same arm's length price $p^{a}=p^{f}=p^{d}$ (where a superscript $a$ denotes the arm's length price). Firm f would prefer to import all intermediates, but is forced to source $\varepsilon q^{f}$ locally. This successive market power model has been examined in Belderbos and Sleuwaegen $(1997,106-109)$ in case of equal 'landed' costs for intermediates $\left(c^{u}=c^{f}+t\right)$. Here we allow for a potential efficiency advantage of firm $\mathrm{f}$, i.e. a cost advantage greater than unit transport cost. The LCR increases demand for intermediate goods and affects the equilibrium price charged by firm $u$. The profit maximizing price for each positive value of the LCR can be calculated as:

$$
p^{a}=c^{f}+t+\frac{(1+\varepsilon)}{\left(1-\varepsilon+\varepsilon^{2}\right)}\left(1-c^{f}-t\right) / 4+\left(c^{u}-c^{f}-t\right) / 2
$$


The intermediate good price is a mark-up higher than the export costs of firm f. The price is an increasing function of the LCR up to a level, at which it declines with a further rise in the LCR. ${ }^{14}$ This non-linearity arises because at high levels of the LCR, a further rise in the price has a large effect on average cost in the downstream industry, depressing demand for final and intermediate goods. In case firm $\mathrm{f}$ has an efficiency advantage, i.e. in case the marginal cost of upstream firm $\mathrm{u}$ is high, it has to set the market price higher to maintain a sufficient margin.

Variable profits of firm $\mathrm{f}$ can be expressed as a function of the price of the intermediate:

$$
\Pi_{N L}^{f}=\left[1-c^{f}-t+(1-2 \varepsilon)\left(p^{a}-c^{f}-t\right)\right]^{2} s / 9
$$

Profits of firm $\mathrm{f}$ are strongly decreasing in the LCR. The LCR works both through a direct effect, forcing firm $\mathrm{f}$ to procure intermediates at higher marginal cost, and through an indirect effect: a rise in the LCR in itself increases $p^{a}$ up to a point. For high LCRs profits are still decreasing but at a lower pace since the effect through the intermediate good price is reversed.

If firm $\mathrm{f}$ chooses FDI, its variable profits are:

$$
\Pi_{N F}^{f}=s\left[\frac{5}{4}\left(1-c^{f}\right)+\frac{1}{2}\left(c^{u}-c^{f}\right)\right]^{2} / 9
$$

Profits depend on the relative cost position of firm $\mathrm{f}$, the size of the market, and the intensity of demand $\left(1-c^{f}\right)$. Firm $\mathrm{f}$ chooses FDI if $\Pi_{N F}^{f}>\Pi_{N L}^{f}+G$. FDI is more likely to be chosen the lower plant setup cost $G$ (i.e. the smaller the economies of scale in intermediate goods production), the larger the market (i.e. the easier economies of scale can be reaped in case of local production), the higher the unit transport cost, and the greater the efficiency advantage of firm $\mathrm{f}$. The LCR increases the likelihood that FDI is chosen by reducing profits under local sourcing. 
Consider now the case where the domestic firms have chosen cooperation in the first stage of the game. The domestic firms behave as a vertically integrated firm. If firm $\mathrm{f}$ chooses FDI, profits of firm $\mathrm{f}$ follow the standard expression for Nash-Cournot duopoly profits:

$$
\Pi_{C F}^{f}=s\left[1-c^{f}+\left(c^{u}-c^{f}\right)\right]^{2} / 9
$$

By comparison with (8) it is clear that profits of firm $\mathrm{f}$ are lower than in the non-cooperation case $\left(\Pi_{C F}^{f}<\Pi_{N F}^{f}\right)$. The host country firms have improved their competitive position by eliminating the mark-up on intra-group deliveries of the intermediate good and this negatively affects variable profits of firm $\mathrm{f}$.

The cooperating domestic firms may prefer the foreign firm not to engage in FDI as local production reduces their variable profits by lowering marginal costs of firm f. ${ }^{15}$ The host country firms can commit to sell intermediate goods to the foreign firm at a unit price which makes local sourcing of $\varepsilon q^{f}$ units marginally more profitable than net profits under FDI and cooperation in (9): $\Pi_{C L}^{f}>\Pi_{C F}^{f}-G$. For convenience, it is assumed that if the foreign firm is indifferent between FDI and local sourcing, it chooses the latter. Profits of firm $\mathrm{f}$ under local sourcing and vertical cooperation are:

$$
\Pi_{C L}^{f}=s\left[1-2\left(c^{f}+t\right)+c^{u}-2 \varepsilon\left(p^{f}-c^{f}-t\right)\right]^{2} / 9
$$

Profits decline in the LCR and in the price of the intermediate, and increase with the efficiency advantage of firm $\mathrm{f}$. Let the FDI pre-empting price be denoted by $p^{f^{*}}$. Using (9) and (10) we get the expression for the FDI pre-empting price:

$$
p^{f^{*}}=c^{f}+t+\frac{1}{2 \varepsilon}\left[1-2\left(c^{f}+t\right)+c^{u}-\sqrt{\omega}\right], \forall \varepsilon>0
$$

\footnotetext{
${ }^{14}$ This level can be calculated as $\sqrt{ } 3-1 \approx 0.73$.

${ }^{15}$ It is assumed that the FDI threat is credible. If this is not the case, it is optimal for the cooperating domestic firms to force the exit of firm $\mathrm{f}$ through vertical foreclosure. A sufficient condition for a credible FDI threat is the existence of positive profits under FDI: $\prod_{C F}^{f}-G>0$ This may not be a necessary condition: since firm $\mathrm{f}$ has already invested in a local assembly plant, exit may not occur even if it makes variable losses under FDI.
} 
where $\omega=\left(1-2 c^{f}+c^{u}\right)^{2}-9 G / s$. The pre-empting price is equal to marginal export cost of firm f plus a mark-up. The mark-up (the term between brackets on the right hand side of (11) $)^{16}$ is higher, the lower is the transport cost and the greater are the scale economies relative to the size of the host country market (the greater is $G / S$ ). Both imply disincentives for FDI. It can also be shown that the FDI pre-empting price can be set higher, the smaller the cost advantage of firm $\mathrm{f}$. A smaller efficiency advantage implies lower profit levels of firm $\mathrm{f}$, which makes it less likely that it can recoup the fixed cost G in case of FDI. An increase in the LCR, on the other hand, is associated with a lower FDI pre-empting price. A LCR increase forces firm $\mathrm{f}$ to source more intermediate goods at a premium, driving down its profits. The FDI pre-empting price has to be reduced to keep profits at the FDI threshold level.

In conclusion, the FDI decision depends crucially on the decision by the domestic firms whether to cooperate in the first stage of the game. FDI will not occur in case of vertical cooperation as long as the host country firms find a FDI pre-empting strategy beneficial. The introduction and further increases in the LCR in that case have no effect on the FDI decision, since host firms adapt the price on deliveries to firm $\mathrm{f}$ in response. In general, the incentives for FDI are lowered in case of cooperation due to the improved relative cost position of host country firms, which results in lower profit levels of firm $\mathrm{f}$. The next section examines under which circumstances vertical cooperation and FDI pre-empting will occur.

\footnotetext{
${ }^{16}$ The condition that the term between brackets is greater than zero is equal to the condition that under free trade DFI is not beneficial for the multinational: $\prod_{C F^{*}}^{f}<\Pi_{C L^{*}}^{f}+G$. This condition holds by assumption (5b).
} 


\subsection{The Decision to Cooperate}

We now consider the cooperation decision by domestic firms in the first stage of the game by examining the payoffs corresponding to the different outcomes of the game.

Non-cooperation with Local Sourcing

If the host country firms do not cooperate and firm $\mathrm{f}$ then chooses local sourcing, profits of firm d are:

$$
\Pi_{N L}^{d}=\left[\left(1-c^{f}-t\right) \frac{5 \varepsilon^{2}-5 \varepsilon+2}{\varepsilon^{2}-\varepsilon+1}-\left(c^{u}-c^{f}-t\right)(4-2 \varepsilon)\right]^{2} s / 144
$$

The first term first decreases in the LCR and only recovers to the free trade level if the LCR is set to unity. This negative effect of the LCR arises because the increase in $p^{a}$ associated with a rise in the LCR hurts firm $\mathrm{d}$ (which sources all its intermediates from $\mathrm{u}$ ), more than firm $\mathrm{f}$ (which only sources up to the local content requirement). ${ }^{17}$ The second term depends on the efficiency advantage of firm $\mathrm{f}$ and is increasing in the LCR. The greater the efficiency advantage of firm $\mathrm{f}$, the greater its cost increase if it is forced to procure intermediates from $\mathrm{u}$, and the greater the improvement in the relative cost position of firm $\mathrm{d}$. It can be derived that the LCR cannot increase profits of firm $\mathrm{d}$ as long as $p^{a}$ increases in response to LCR.

Profits of the upstream firm $u$ are derived as:

$$
\Pi_{N L}^{u}=\frac{\left[\left(1-c^{f}-t\right)(1+\varepsilon)-2\left(c^{u}-c^{f}-t\right)\left(\varepsilon^{2}-\varepsilon+1\right)\right]^{2}}{\varepsilon^{2}-\varepsilon+1} s / 24
$$

In the absence of an efficiency advantage of firm $\mathrm{f}$, profits of firm $\mathrm{u}$ are a monotonously increasing function of the LCR. Profits are lower the weaker the relative cost position of firm u. The imposition of the LCR reduces direct competition from $\mathrm{f}$ and the negative effect of its cost 
disadvantage, but only up to a point (at $\varepsilon=0.5$ ). After this point, further increases in the LCR have a stronger effect on average cost in the final goods industry which depresses demand. The aggregate effect of the LCR is an increase in the upstream firm's profits for all but the highest levels of the LCR. ${ }^{18}$ It can also be shown that the sum of profits of firms $\mathrm{d}$ and $\mathrm{u}, \Pi_{N L}^{T}=\Pi_{N L}^{d}+\Pi_{N L}^{u}$, is an increasing function of the LCR, but this increase is smaller in the presence of an efficiency advantage of firm $\mathrm{f}$.

\section{Non-Cooperation with FDI}

If under non-cooperation firm $\mathrm{f}$ chooses FDI, profits of firms $\mathrm{d}$ and $\mathrm{u}$ become:

$$
\begin{aligned}
& \Pi_{N F}^{d}=\left[\frac{1}{2}\left(1-c^{f}\right)-\left(c^{u}-c^{f}\right)\right]^{2} s / 9 \\
& \Pi_{N F}^{u}=\left[\frac{1}{2}\left(1-c^{f}\right)-\left(c^{u}-c^{f}\right)\right]^{2} s / 6
\end{aligned}
$$

Under FDI firm $\mathrm{f}$ avoids both the LCR and transport cost $t$. This allows it to increase profits, partly at the cost of firms $u$ and d. Profits of firm $d$ are not necessarily lower than under local sourcing in (12), since small LCRs negatively affect the latter. Profits of firm u are always lower than profits under local sourcing in (13), as are total domestic profits $\left(\Pi_{N F}^{T}<\Pi_{N L}^{T}\right){ }^{19}$ Hence, if the imposition of the LCR induces FDI by firm $\mathrm{f}$, the host country firms have a strong incentive to cooperate and set the price of the intermediate strategically to pre-empt this investment.

\footnotetext{
${ }^{17}$ See Belderbos and Sleuwaegen (1997) for a more detailed discussion.

${ }^{18}$ It can be derived that a sufficient condition for $\partial \Pi_{N L}^{u} / \partial \varepsilon>0$ is $\varepsilon<0.815$.

${ }^{19}$ In case of free trade, profits under non-cooperation and export are already higher than profits under noncooperation and FDI. This can be seen by summing up (14) and (15) which gives

$\prod_{N F^{*}}^{T}=\prod_{N F}^{T}=5\left[\frac{1}{2}\left(1-c^{f}\right)-\left(c^{u}-c^{f}\right)\right]^{2} s / 18$, while summing up (12) and (13) after substituting $\varepsilon=0$ gives $\prod_{N L^{*}}^{T}=5\left[\frac{1}{2}\left(1-c^{f}-t\right)-\left(c^{u}-c^{f}-t\right)\right]^{2} s / 18$, which is
} greater. The imposition of the LCR increases NL profits but leaves NF profits unaffected, increasing this difference. 
Vertical cooperation delivers efficiency gains through the elimination of successive mark-ups similar to the case of vertical integration. It also provides strategic gains, i.e. the potential of strategic pricing of intermediates sold to firm $\mathrm{f}$, but involves a cost $F^{T}$. If the cooperating firms set the price $p^{f}$ at the level which pre-empts FDI by firm $\mathrm{f}$, joint profits of the host country firms are:

$$
\begin{aligned}
\Pi_{C L}^{T}= & s\left[1-c^{f}-t-2\left(c^{u}-c^{f}-t\right)+\varepsilon\left(p^{f^{*}}-c^{f}-t\right)\right]^{2} / 9 \\
& +\varepsilon q^{f}\left(p^{f^{*}}-c^{u}\right)
\end{aligned}
$$

The first term on the right hand side of (16) represent profits earned on the final goods market, and the second term expresses profits on the sale of intermediates to firm $\mathrm{f}$. Given the FDI pre-empting price, an increase in the LCR increases profits on the final goods market, and, as long as the FDI pre-empting price is higher than marginal cost $c^{u}$, profits on the sale of intermediates to firm $\mathrm{f}$. However, with each increase in the LCR, the FDI pre-empting price has to be reduced in order to keep profits of firm $\mathrm{f}$ at the level attainable under FDI. The implication is that profits on the final goods market are not affected by changes in the LCR. ${ }^{20}$ Profits on the intermediate are also unaffected by the LCR in case of equal efficiency $\left(c^{u}=c^{f}+t\right)$, but decrease in the LCR if firm $\mathrm{f}$ has an efficiency advantage. In the latter case, the FDI pre-empting price has to be reduced by such a large margin in response to an increase in the LCR that total profits decrease. This implies that, if an LCR is imposed to protect an inefficient domestic industry, this industry benefits more, the smaller the LCR. In case of equal efficiency, the one-off strategic gain of the imposition of the LCR (which allows for price discrimination and FDI pre-empting) is what matters, not the level of the LCR.

It can easily be derived that as long as $p^{f^{*}}>c^{u}$ (a sufficient but not a necessary condition is that firm $f$ does not have an efficiency advantage), host country firms' variable profits under cooperation exceed profits under free trade $\left(\Pi_{C L}^{T}>\Pi_{C L^{*}}^{T}\right.$. Hence, while cooperation was not beneficial under free trade due to the associated cost (condition (5c): 
$\left.\Pi_{C L^{*}}^{T}<\Pi_{N L^{*}}^{T}+F^{j} / \gamma^{j}\right)$, the introduction of the LCR opens the possibility of cooperation. Cooperation and FDI pre-empting is the likely equilibrium outcome of the game if $\Pi_{C L}^{T}$ is sufficiently higher than both $\Pi_{N L}^{T}$ and $\Pi_{N F}^{T}$ (conditions (2b) and (2c)). ${ }^{21}$ Since $\Pi_{C L}^{T}>\Pi_{N L^{*}}^{T}>\Pi_{N F}^{T}$, condition (2c) is likely to hold as long as the cost $F^{T}$ is not too high. In addition, a small LCR has the maximum positive effect on cooperation profits but only a small positive effect on profits under non-cooperation and local sourcing. This is because a small LCR only has a correspondingly small effect on $\Pi_{N L}^{T}$ (in (12) and (13)), while it allows for a high FDI pre-empting price in (11) and a jump in profits in case of cooperation. In case there are important economies of scale in intermediate goods production ( $G$ large), the FDI pre-empting price and profits under cooperation are particularly high and a small LCR increases the likelihood that the host country firms choose to cooperate. If the LCR is set a higher levels, profits under noncooperation and local sourcing rise while profits under cooperation may decline (in case domestic firms have an inefficiency disadvantage). The incentives to cooperate decline in the LCR.

\section{Cooperation with FDI}

There are circumstances under which the host country firms will not find a FDI pre-empting strategy beneficial. If firm $\mathrm{f}$ has an efficiency advantage and if economies of scale in intermediate goods production are not important ( $G$ small), then the FDI pre-empting price falls below the marginal cost of firm $u$. In other words, the host country firms have to sell intermediates below marginal cost in order to keep the foreign firm from investing in a local plant. ${ }^{22}$ In these circumstances, a FDI pre-empting strategy is unlikely to be beneficial. In that case, FDI will occur and cooperation only delivers efficiency gains. Total domestic variable profits under cooperation become:

$$
\Pi_{C F}^{T}=4\left[\frac{1}{2}\left(1-c^{f}\right)-\left(c^{u}-c^{f}\right)\right]^{2} s / 9
$$

\footnotetext{
${ }^{20}$ If (11) is substituted in the first term on the right hand side of (16), the LCR disappears from the expression.

${ }^{21}$ Condition (2a) holds by assumption under FDI pre-empting.

${ }^{22} \mathrm{It}$ is possible that such strategic dumping is the equilibrium outcome, as long as the losses on sales to the foreign firm are limited and can be recouped on the final goods market.
} 
The efficiency advantage allows the host country firms to increase variable profits in comparison with the sum of non-cooperation profits under FDI in (14) and (15). However, this increase is not sufficient to offset the cost of cooperation. This can be seen as follows. In case of FDI the LCR is not binding such that profits under free trade are equal to profits with an LCR in place $\left(\Pi_{C F^{*}}^{T}=\Pi_{C F}^{T}\right)$, while profits under FDI are always lower than profits under export and free trade, hence $\Pi_{C F}^{T}<\Pi_{C L^{*}}^{T}$. We have also seen that total profits under non-cooperation and local sourcing (NL) are an increasing function of the LCR such that $\Pi_{N L}^{T}>\Pi_{N L^{*}}^{T}$. Since we have from (5c) that $\Pi_{C L^{*}}^{T}<\Pi_{N L^{*}}^{T}+F^{j} / \gamma^{j}$, it follows that $\Pi_{C F}^{T}<\Pi_{N L}^{T}+F^{j} / \gamma^{j}$ (condition (4c) does not hold). In other words, if the domestic firms do not cooperate in the free trade situation, they will certainly not cooperate in response to the LCR if such cooperation is associated with FDI. Also, we know that the incentives to cooperate are smaller in case of FDI compared with export: $\left(\Pi_{C F^{*}}^{T}-\Pi_{N F^{*}}^{T}\right)=\left(\Pi_{C F}^{T}-\Pi_{N F}^{T}\right)<\left(\Pi_{C L^{*}}^{T}-\Pi_{N L^{*}}^{T}\right)$, since profit levels under export are higher due to the transport cost firm $\mathrm{f}$ has to pay. ${ }^{23}$ Inserting this in $(5 \mathrm{c})$ it follows that $\Pi_{C F}^{T}<\Pi_{N F}^{T}+F^{j} / \gamma^{j}$ (4b does not hold). Hence, in case firm $\mathrm{f}$ chooses FDI in case of noncooperation, the host firms neither have an incentive to cooperate. The implication is that cooperation and FDI (CF) is ruled out as an equilibrium outcome.

\subsection{Cost structure and Cooperation}

What are the precise conditions under which a FDI pre-empting strategy is not beneficial? If FDI pre-empting is not beneficial and with CF ruled out, the host country firms will either earn NF or NL profits. Under the circumstances which make FDI pre-empting less beneficial (limited economies of scale and an efficiency advantage of firm $\mathrm{f}$ ), the market price of intermediates in case of NL in (6) is high and $\Pi_{N L}^{f}$ in (7) is at a low level. Given the assumed small fixed cost $G$, it is highly unlikely that (1a) holds at more than marginal levels of the LCR, such that firm $\mathrm{f}$ will choose to invest and $\mathrm{NF}$ is the equilibrium outcome. The relevant comparison for host country firms

\footnotetext{
${ }^{23}$ This conditions translates to: $\left[1-2 c^{u}+c^{f}\right]^{2}<\left[1-2 c^{u}+c^{f}+t\right]^{2}$, which holds.
} 
therefore is between profits under CL and NF. Using (16) and (11) and (14) and (15) we derive that $\Pi_{C L}^{T}<\Pi_{N F}^{T}$ holds if:

$$
\left(c^{u}-c^{f}\right)>\frac{\left(1+c^{f}-2 c^{u}\right)^{2} / 8-t(1-\varepsilon) \sqrt{\omega}+15 G / 4 s}{1-2 c^{f}+c^{u}-(1-\varepsilon) \sqrt{\omega}}
$$

Cooperation breaks down if the cost advantage of firm $\mathrm{f}$ reaches a certain threshold level. This level is lower, the smaller the scale economies, the larger the market, the higher the LCR, and the higher the transport cost: all factors which reduce the FDI pre-empting price in (11). Equation (18) is a necessary condition for cooperation to be beneficial. Whether cooperation is chosen also depends on the cost of cooperation relative to the bargaining power of firm $\mathrm{u}$ or $\mathrm{d}$. The gain in variable profits should offset the cost of cooperation: $\Pi_{C L}^{T}>\Pi_{N F}^{T}+F^{j} / \gamma^{j}$ in (2c). In general, if the institutional setting is such that the cost of cooperation is very high, the gains in variable profits in case of cooperation may not be sufficient compensation even when economies of scale allow for a high FDI pre-empting price. These are the circumstances under which non-cooperation and local sourcing (NL) is most likely to arise.

It is useful to illustrate the effect of cost structure on equilibrium outcome by examining profit functions for some numerical examples. Figures 1a - 1c represent three contrasting cases, each associated with a different equilibrium outcome. Case 1 represents the equal efficiency, economies of scale case which typically leads to CL equilibrium (the parameter settings are: $c^{U}=0.3$, $\left.c^{f}=0.25, t=0.05, s=1, F^{T}=0.03, G=0.06\right) .{ }^{24}$ In Case 2, economies of scale are limited and the foreign firm has an efficiency advantage $\left(c^{U}=0.3, \quad c^{f}=0.15, \quad t=0.05, \quad s=1\right.$, $F^{T}=0.03 G=0.025$ ), leading to NF equilibrium. Case 3 is as Case 1 , but now the cost of cooperation is high ( $c^{U}=0.3, c^{f}=0.25, t=0.05, s=1, F^{T}=0.08, G=0.06$ ) and NL equilibrium will result. Figures 1a - 1c depict total host country firm profits for each of the four possible outcomes (CL, NL, NF, CF) as a function of the LCR. The bold line shows equilibrium profits as a function of the LCR. The vertical line marks the level of the LCR at which firm $f$ chooses FDI in

\footnotetext{
${ }^{24}$ For convenience it is assumed that bargaining power and costs of cooperation are symmetric: $\gamma^{d}=\gamma^{u}=1$ and $F^{u}=F^{d}$
} 
case of non-cooperation $\left(\Pi_{N F}^{f}>\Pi_{N L}^{f}+G\right)$ : on right side of this line, $\mathrm{NL}$ is not an equilibrium outcome.

In Figure 1a (Case 1), the introduction of the LCR allows host country firms to sharply increase joint profits: free trade profits (at the level where the NL profit line crosses the Y-axis) are doubled. CL profits are unaffected by the level of the LCR in this equal cost case. For LCRs greater than 0.69, NL profits exceed CL profits. However, NL equilibrium is not feasible since firm $\mathrm{f}$ would invest in response (for LCRs greater than 0.61 ) and NF would result. Hence, CL profits are the maximum attainable and CL remains the equilibrium outcome. In Figure 1b (Case 2), the vertical line marking the FDI choice by firm $f$ has shifted to the left, due to the smaller scale economies and the presence of an efficiency advantage. The CL profit function has shifted downward and is now a declining function of the LCR. Although NL provides the highest profits, it is not an equilibrium outcome for LCRs higher than 0.11 and NF results. It can also be seen that the introduction of a LCR higher than 0.11 reduces profits below the free trade level. In Figure 1c (Case 3) the CL profit line has shifted downwards as a result of the higher cost of cooperation (the $\mathrm{CF}$ profit line has also shifted downward to the extent that the CF outcome is loss-making). NL is the equilibrium outcome up to a relatively high level of the LCR (0.61), after which FDI (NF) occurs.

\subsection{Summary}

The introduction of the LCR can have markedly contrasting consequences, corresponding to the various outcomes of game, and depending on the cost conditions in the industry. If economies of scale are important in intermediate good production and domestic firms do not have an efficiency disadvantage, a small LCR increases the likelihood that host country firms decide to cooperate. Cooperation allows the host country firms to set the price of intermediates sold to the foreign firm strategically to pre-empt FDI, and cooperation delivers strategic as well as efficiency gains. The introduction of the LCR increases profits of the domestic firms and reduces profits of the foreign firm. This FDI pre-empting scenario resembles the case of EU color television and cathode ray tube production discussed in section 1. On the other hand, if economies of scale are not important relative to the size of the market and if host country firms are inefficient, the introduction of the LCR is likely to induce FDI, while it makes cooperation less likely to occur. In this case, the introduction 
of the LCR reduces profits of both the host country firms $\left(\Pi_{N F}^{T}<\Pi_{N L^{*}}^{T}\right)$ and the foreign multinational $\left(\Pi_{N F}^{f}-G<\Pi_{N L^{*}}^{T}\right.$ ). This FDI scenario corresponds with the experience of LCRs and Japanese FDI in manufacturing plants for a number of other television components such as power sources and plastic moldings. In a third scenario, the LCR does not induce cooperation nor FDI. This outcome is most likely to arise if the cost of cooperation is high and economies of scale are important. In this scenario, the LCR allows the upstream firm to increase its profits at the cost of both downstream firms.

\section{Welfare Implications}

Total domestic welfare $W$ consists of consumer surplus and the profits of the domestic firms, while the profits of the firm $\mathrm{f}$ are assumed to be expatriated: $W=C S+\Pi^{d}+\Pi^{u}$, where $C S$ denotes consumer surplus. The consequences for consumers are considered first after which total domestic welfare is discussed.

\section{Consumer Surplus}

We examine the effects of the LCR on consumer surplus by comparing the level of consumer surplus under the initial situation of free trade ( $\left.\mathrm{NL}^{*}\right)$ with the level of consumer surplus under the various outcomes of the game after the introduction of the LCR. Consumer surplus before the introduction of the LCR is:

$$
C S_{N L^{*}}=\left[\frac{7}{4}\left(1-c^{f}\right)-\frac{1}{2}\left(c^{u}-c^{f}\right)-\frac{5}{4} t\right]^{2} s / 18
$$

Consumer surplus is a negative function of average cost in the final goods industry. The latter increase in the marginal cost of the foreign firm, the efficiency disadvantage of the host country's firm $\mathrm{u}$, and transport cost.

If the introduction of the LCR induces FDI but no cooperation consumer surplus is: 


$$
C S_{N F}=\left[\frac{7}{4}\left(1-c^{f}\right)-\frac{1}{2}\left(c^{u}-c^{f}\right)\right]^{2} s / 18
$$

The LCR increases consumer surplus because FDI is associated with lower variable cost of firm $\mathrm{f}$ which avoids the transport cost $\left(C S_{N F}>C S_{N L^{*}}\right)$. If the LCR leads to non-cooperation while firm $\mathrm{f}$ chooses local sourcing consumer surplus is:

$$
C S_{N L}=\left[\left(1-c^{f}-t\right)\left(\frac{7}{4}-\frac{3}{4} \frac{\varepsilon}{\varepsilon^{2}-\varepsilon+1}\right)-\frac{1}{2}\left(c^{u}-c^{f}-t\right)(1+\varepsilon)\right]^{2} s / 18
$$

The LCR increases market power of firm $f$ and the price on the intermediate goods market, increasing costs in the final goods industry and reducing consumer surplus. Consumer surplus is always lower than consumer surplus under free trade in (19) and this difference is increasing in the LCR: $C S_{N L}<C S_{N L^{*}}$. The LCR also exacerbates the negative effect on consumer surplus of a cost disadvantage of firm u. Finally, if the LCR induces a FDI pre-empting strategy by the host country firms, consumer surplus is:

$$
C S_{C L}=\left[\frac{6}{4}\left(1-c^{u}\right)+\frac{1}{2} \sqrt{\omega}\right]^{2} s / 18
$$

On the one hand, consumers gain as the host country firms cooperate and eliminate the inefficiency associated with the mark-up for arm's length transactions. On the other hand, intermediate goods are sold to firm $\mathrm{f}$ at a price $p^{f^{*}}>c^{f}+t$, which increases costs of firm $\mathrm{f}$. Comparing (22) and (19) it is derived that consumer surplus increases compared with the free trade situation $\left(C S_{C L}>C S_{N L^{*}}\right)$ if: $2 \sqrt{\omega}>\left(1-c^{f}-t\right)+4\left(c^{u}-c^{f}-t\right)$. This condition is more likely to be fulfilled if economies of scale are limited relative to the size of the market ( $G / s$ low), since the FDI pre-empting price is set lower and the consequences of the LCR for consumer surplus are less serious. Consumer surplus is more likely to increase the higher the transport cost: this cost reduces consumer surplus under free trade but has no effect on consumer surplus under FDI pre- 
empting in (22). It can be shown that consumer surplus is more likely to rise, the lower the cost $c^{f}$ of the foreign firm (resulting in a higher efficiency advantage). This situation leads to a lower FDI pre-empting price with positive consequences for consumer surplus. However, under the above conditions it is also more likely that FDI pre-empting is not beneficial to the host country firms. In other words, if industry conditions are such that FDI pre-empting is likely to occur as a response to the imposition of the LCR, it is also less likely to have positive welfare consequences for consumers.

Figure 2 illustrates the consequences for consumer surplus by examining the three contrasting cases described in section 3.3. In the CL equilibrium case (Case 1) the introduction of the LCR leads to a small decline in consumer surplus compared with the free trade equilibrium. In Case 2 (NF equilibrium for LCRs exceeding 0.11) consumer surplus increases. In Case 3, NL equilibrium (up to a value of the LCR of 0.61 ) is associated with a substantial decline in consumer surplus.

\section{Total Domestic Welfare}

The different effects of the introduction of the LCR on profits of firm $u$ and firm $d$ and consumer surplus do not allow us to derive an unambiguous ranking of outcomes in terms of total domestic welfare. We compare the welfare outcomes with the free trade outcome and illustrate welfare effects by examining the three cases described in the previous section.

If the imposition of the LCR induces FDI but no cooperation (NF), consumer surplus rises while total host country profits decline. It can be shown that the rise in consumer surplus always more than offsets the reduction in profits: host country welfare increases. ${ }^{25}$ In case NL is the equilibrium outcome, the LCR increases profits but reduces consumer surplus. In the absence of an efficiency advantage of firm $\mathrm{f}$, it has been shown that host country welfare remains below welfare under free trade for all but the highest levels of the $\mathrm{LCR} .{ }^{26}$ If firm $\mathrm{f}$ has an efficiency advantage, the LCR is even less likely to increase domestic welfare. The LCR forces firm $\mathrm{f}$ to procure high-cost

\footnotetext{
${ }^{25}$ The negative profit shifting effect of the reduction in firm f's marginal cost weighs less because profits of domestic producers are relatively small, given the inefficiency associated with the mark-up on arm's length sales of intermediates. Conversely, a 'raising rival's cost' strategy under these circumstances cannot increase host country welfare [Sleuwaegen et al. (forthcoming)].

${ }^{26}$ See Belderbos and Sleuwaegen (1997). Welfare can only rises above the free trade level if $\mathcal{E}>0.87$. The qualitative result also holds in case of successive oligopoly (multiple upstream and downstream firms).
} 
intermediates, increasing industry costs and reducing consumer surplus more strongly, while the positive effect of the LCR on host country profits is reduced.

If the LCR induces FDI pre-empting cooperation, host country firms' profits increase. Consumer surplus may increase, but only in the circumstances which make FDI pre-empting cooperation less likely to occur. Numerical analysis shows that the positive effect on profits in most cases more than offsets the negative effect on consumer surplus. Welfare can decline, but only in a setting where both the cost of cooperation and the plant setup cost $G$ are high and the foreign firm has an efficiency advantage. In this situation, FDI pre-empting (CL) allows for only a limited increase in host country firms' profits and leads to a high price of intermediates sold to firm $\mathrm{f}$, which results in a substantial decline in consumer surplus.

The effects on domestic welfare are illustrated in Figure 3, which sets out total domestic welfare as a function of the LCR for the three case. The introduction of the LCR increases welfare in case of CL equilibrium (Case 1). The welfare graphs for Case 2 illustrates that NF equilibrium results in higher welfare levels. Welfare is reduced in case of NL equilibrium (Case 3).

In conclusion, if the LCR results in FDI pre-empting, cooperation allows for efficient rent shifting, leading to a substantial increase in host country profits. This increase exceeds a likely decline in consumer surplus such that domestic welfare rises. In case the LCR induces FDI, domestic welfare increases, but in this case the gains for consumers exceed the decline in host country profits. Finally, in case of the non-cooperation and local sourcing outcome, profits of the intermediate goods producer rise but at the cost of a reduction in both consumer and total welfare.

\section{Conclusions}

We examined the effects of a local content requirement (LCR) in the context of potential vertical cooperation between a host country's upstream and downstream producers and foreign direct investment (FDI) in upstream manufacturing by a foreign multinational. A three stage game was developed in which the host country firms first decide on cooperation after which the foreign firm decides on FDI. The relationship-specific investment which sustains cooperation between the 
host country firms also allows them to commit to a FDI pre-empting strategy through manipulation of the price of intermediates supplied to the foreign firm. The set-up was inspired by the case of LCRs imposed on Japanese manufacturers of color televisions in the European Union, which led to Japanese FDI for some components, but local sourcing from vertically integrated EU firms for others.

We showed that the equilibrium outcome of this game is strongly dependent on the presence of economies of scale in the upstream industry, a possible cost advantage of the foreign multinational, and the cost of cooperation. In the presence of economies of scale and equal variable costs, the introduction of a LCR is most likely to induce vertical cooperation and a FDI pre-empting strategy. In this scenario, the LCR both results in an efficiency gain as vertical cooperation eliminates the internal mark-up associated with arm's length deliveries, and a strategic gain as FDI is avoided. The LCR is effective as a profit shifting instrument (profits of domestic firms increase). Although consumer surplus is likely to be negatively affected, total domestic welfare increases. If the host country industry has a cost disadvantage, cooperation may still occur, but high LCRs reduce host country profits and the incentives to cooperate.

If economies of scale are not important and if host country firms have a cost disadvantage, the imposition of the LCR induces FDI but cooperation does not occur. In this scenario, the LCR reduces profits of domestic firms as well as profits of the foreign firm. On the other hand, the reduction in variable costs of the foreign firm results in an increase in consumer surplus, while total domestic welfare increases as well. In a third scenario, which is most likely to arise if the cost of cooperation is high and economies of scale are present, the foreign firm is most likely to choose local sourcing to satisfy the LCR while cooperation is less likely to occur. The LCR shifts profits to the upstream firm, while profits of both downstream firms as well as consumer surplus and total welfare decline.

The findings show that, once FDI and vertical cooperation are taken into account, LCRs can have a broad range of consequences. The presence of market power of upstream firms does not necessarily imply strong output and welfare reducing effects of the LCR as in Belderbos and Sleuwaegen (1997). In contrast with Beghin and Sumner (1992) the LCR does affect the final goods prices in case of vertical cooperation, but the strategic effect of the LCR allows for a more 
effective rent shifting from the foreign multinational to host country firms at smaller cost to consumers. The result that host country welfare also benefits in the FDI scenario corresponds with previous analysis which allowed for FDI but in rather different settings [Richardson (1993), Hollander (1987)].

Our analysis has focused on the conditions under which the introduction of a LCR may foster vertical cooperation between domestic firms and treated these firms as first movers. These features of the model stemmed from our interest in the relationship between LCRs and vertical cooperation and the fact that Japanese manufacturers tended to engage in FDI only after LCRs were imposed. An interesting extension would be to also consider the implications of strategic FDI by granting the foreign firm a first mover advantage. A contrasting extension with different implications is the case where a cost disadvantage of domestic firms derives from unfavorable locational factors, such that the foreign firm also faces a rise in marginal cost if it invests in the host country. ${ }^{27}$ These considerations provide ample scope for future research.

\footnotetext{
${ }^{27}$ As in Belderbos (1997, chapter 3).
} 
Figure 1a: Host Country Firms' Total Profits as a Function of the LCR: Case 1

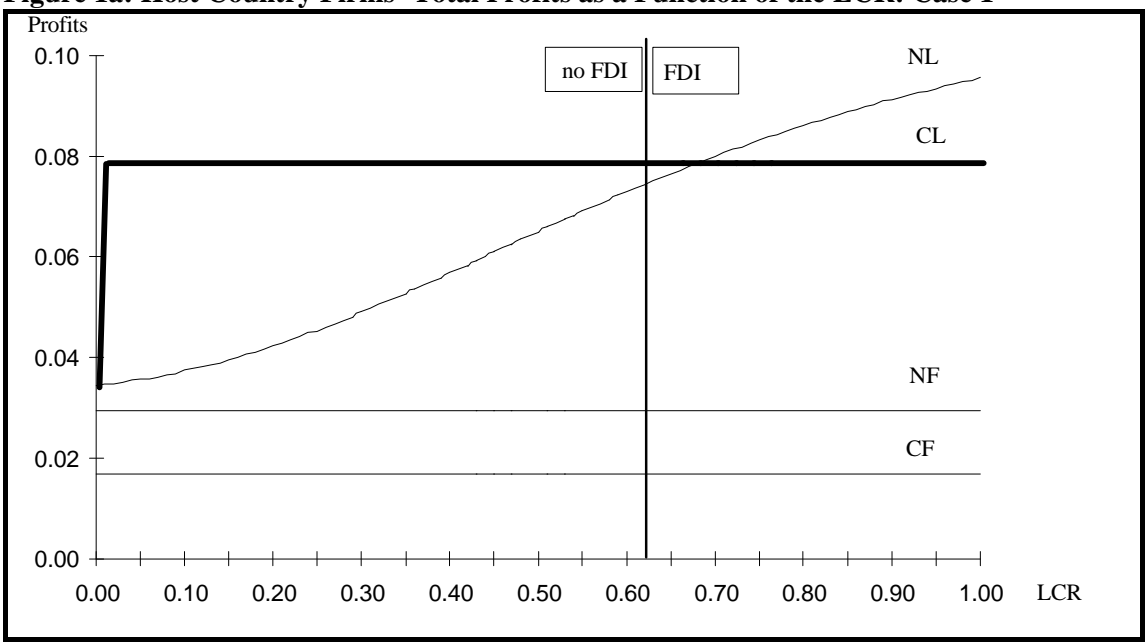

Figure 1b: Host Country Firms' Total Profits as a Function of the LCR: Case 2

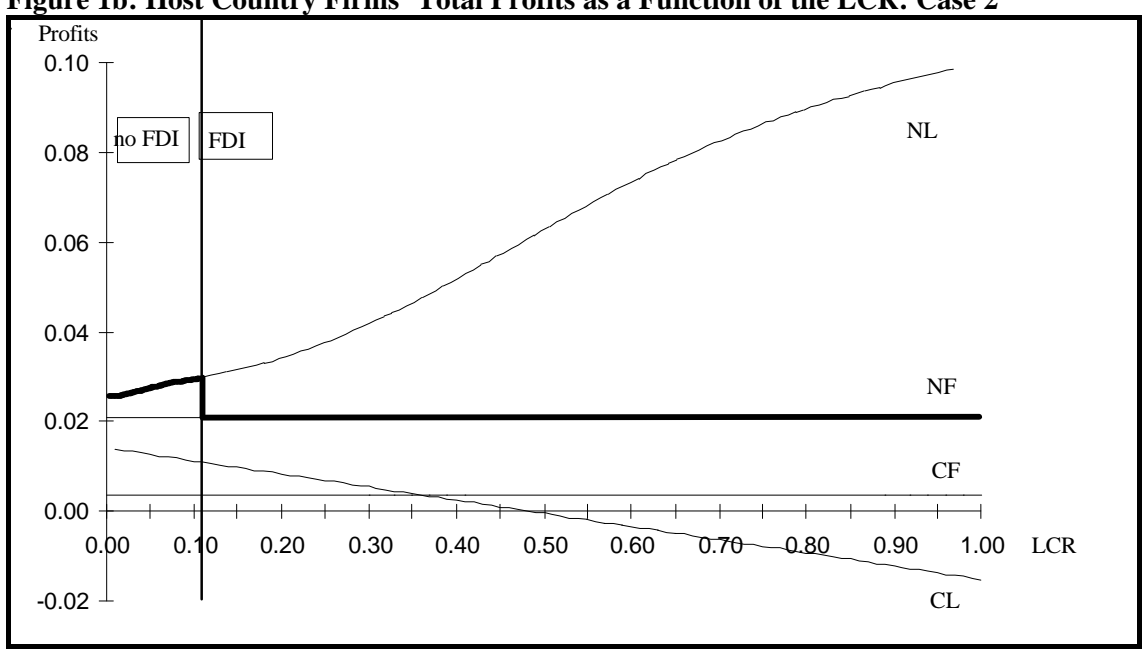

Figure 1c: Host Country Firms' Total Profits as a Function of the LCR: Case 3 


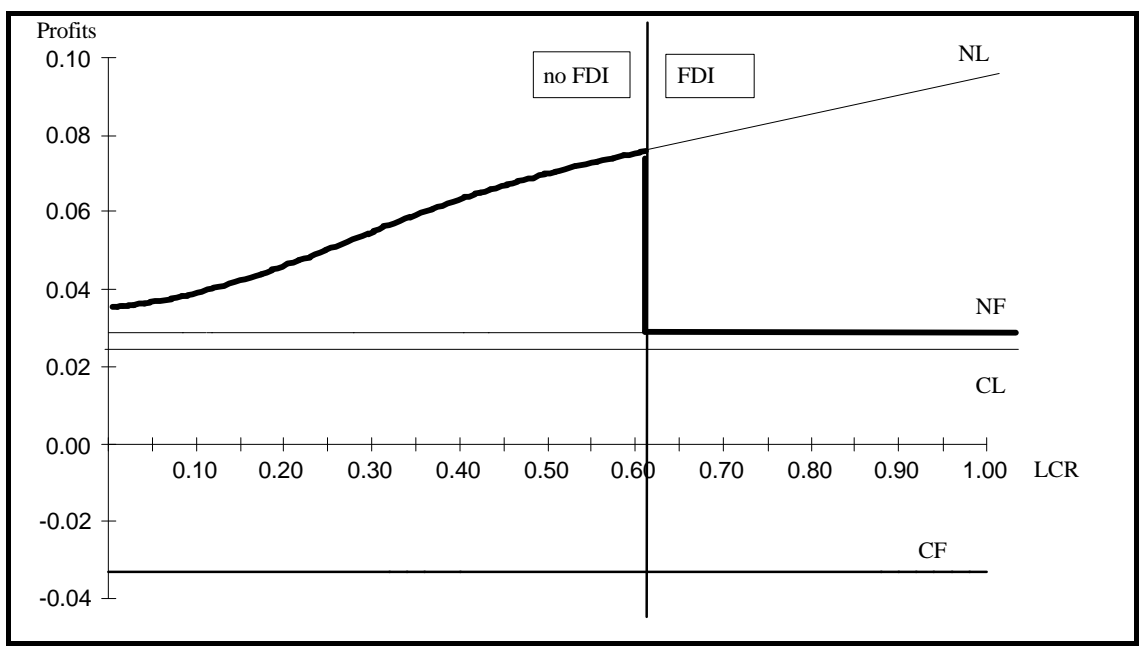


Figure 2: Consumer Surplus as a Function of the LCR: Three Cases

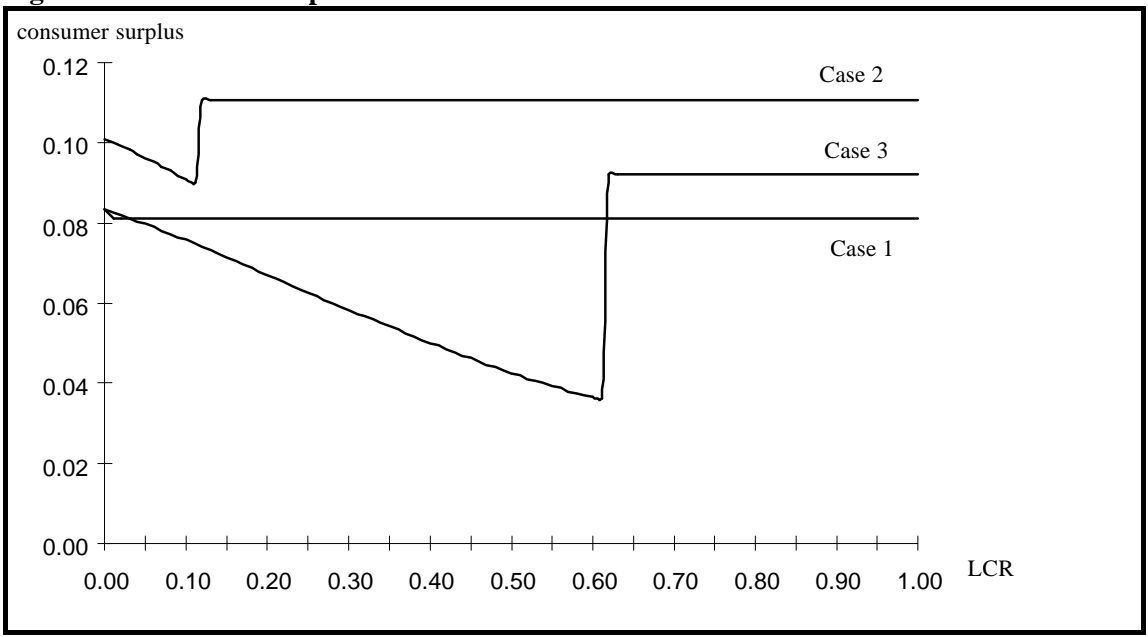

Figure 3: Domestic Welfare as a Function of the LCR: Three Cases

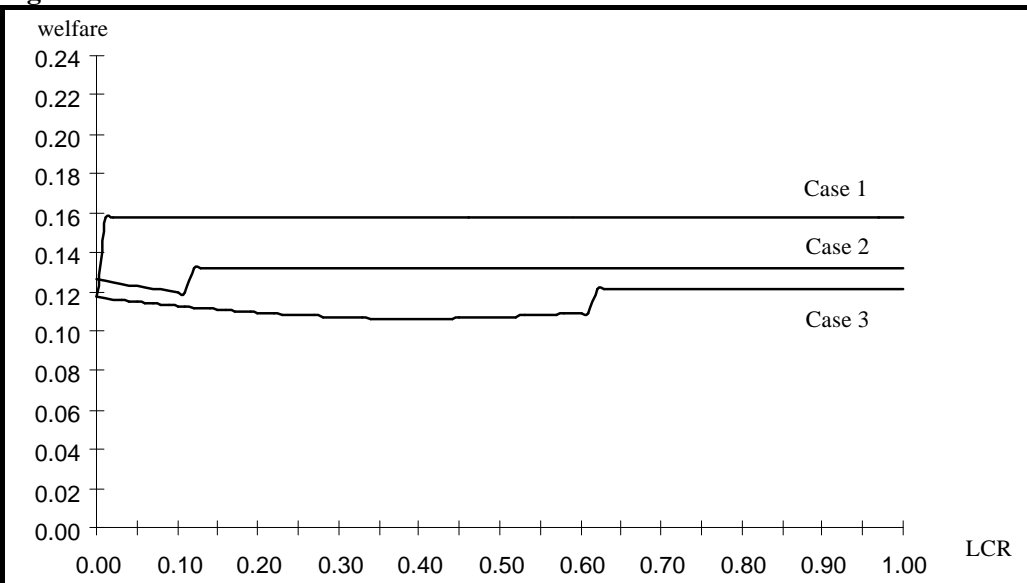




\section{References}

Beghin, J.C., and D.A. Sumner (1992), 'Domestic content requirements with bilateral monopoly,' Oxford Economic Papers 44, 306-316.

Beghin, J.C., and C.A. Knox Lovell (1993), 'Trade and efficiency effects of domestic content protection: the Australian tobacco and cigarette industries,' The Review of Economics and Statistics 75, 623-631.

Belderbos, R.A. (1997), Japanese electronics multinationals and strategic trade policies, (Oxford: Oxford University Press).

Belderbos, R.A. and L.I.E. Sleuwaegen (1997), 'Local content requirement and vertical market structure,' European Journal of Political Economy, Vol. 13, 101-119.

Bughin, J., and S. Vannini (1994), 'Strategic direct investment under unionized oligopoly,' International Journal of Industrial Organization 13, 127-145.

Burton, F.N., and F.H. Saelens (1987), 'Trade barriers and Japanese foreign direct investment in the colour television industry,' Managerial and Decision Economics 8, 285-293.

Chao, C.C., and E.S.H. Yu (1993), 'Content protection, urban unemployment and welfare,' Canadian Journal of Economics 26, 481-492.

Chung, T.Y. (1995), 'On strategic commitment: contracting versus investment,' American Economic Review, AEA Papers and Proceedings, 437-441.

Cordella, T., and S. Vannini (1995), 'Foreign direct investment and strategic trade policies,' A revised version of C.O.R.E. discussion paper no. 9356, Université Catholique de Louvain.

Corden, W.M. (1971) The theory of protection (Oxford: Oxford University Press).

D’Aveni, R.A., and D.J. Ravenscraft (1994), `Economies of integration versus bureaucracy costs: does vertical integration improve performance?' Academy of management Journal 37(5), 1167-1206.

Davidson, C., S.J. Matusz, and M.E. Kreinin (1987), `Analysis of performance standards for direct foreign investments,' Canadian Journal of Economics, 876-890.

Dei, F. (1990), 'A note on multinational corporations in a model of reciprocal dumping,' Journal of International Economics 29, 161-171.

Dixit, A.K., and G.M. Grossman (1982), 'Trade and protection with multistage production,' Review of Economic Studies, 583-594. 
Fung, M.K.Y. (1994), 'Content protection, resource allocation, and variable labour supply,' Canadian Journal of Economics 27, 175-182.

Greenhut, M.L., and H. Ohta (1979), 'Vertical integration of successive oligopolies,' American Economic Review 69, 137-141.

Grossman, G.M. (1981), 'The theory of domestic content protection and content preference,' Quarterly Journal of Economics, 583-603.

Hamel, G., Doz, Y.L., and C.K. Prahalad (1989), 'Collaborate with your competitors - and Win,' Harvard Business Review, 133-139.

Hollander, A. (1987), 'Content protection and transnational monopoly,' Journal of International Economics 23, 283-297.

Krishna, K., and M. Itoh (1988), 'Content protection and oligopolistic interactions,' Review of Economic Studies, 107-125.

Lopez-de-Silanes, F., J.R. Markusen, and T.F. Rutherford (1996), 'Trade policy subtleties with multinational firms', European Economic Review 40, 105-1627.

Motta, M. (1992), 'Multinational firms and the tariff-jumping argument,' European Economic Review 36, 1557-1571.

Motta, M., and G. Norman (1996), 'Does economic integration cause foreign direct investment?', International Economic Review 37, 757-783.

Mussa, M. (1984), 'The economics of content protection,' NBER Working Paper No. 1457.

Porter, M.E. (1986), Competition in global Industries (Boston: Harvard Business School Press).

Richardson, M. (1991), 'The effects of a content requirement on a foreign duopsonist,' Journal of International Economics, 143-155.

Richardson, M. (1993), 'Content protection with foreign capital,' Oxford Economic Papers 45, 103-117.

Rodrik, D., and C.H. Yoon (1989), 'Strategic trade policy when domestic firms compete against vertically integrated rivals,' NBER Working Paper No. 2916.

Salinger, M.A. (1988), 'Vertical mergers and market foreclosure,' Quarterly Journal of Economics $103,345-356$.

Sanna-Randaccio, F. (1996), 'New protectionism and multinational companies,' Journal of International Economics 41, 29-51.

Sleuwaegen, L.I.E, R.A. Belderbos, and C.S.J. Jie-A-Joen (forthcoming), `Cascading contingent protection and vertical market structure,' International Journal of Industrial Organization. 
Smith, A. (1987), 'Strategic investment, multinational corporations and trade policy,' European Economic Review 31, 89-96.

Spencer, B.J., and R.W. Jones (1991), 'Vertical foreclosure and international trade policy,' Review of Economic studies 58, 153-170.

Spencer, B.J., and R.W. Jones (1992), 'Trade and protection in vertically related markets,' Journal of international Economics 32, 31-55.

Tyson, L. (1992), 'Who's bashing whom?: trade conflict in high-technology industries,' (Washington DC: Institute for International Economics).

Vousden, N. (1987), 'Content protection and tariffs under monopoly and competition,' Journal of International Economics 23, 263-282.

Waterson, M. (1982), 'Vertical integration, variable proportions and oligopoly,' Economic Journal 92, 129-144.

Williamson, O.E. (1989), 'Transaction cost economics,' In Handbook of Industrial Organization (Volume I), ed. R. Schmalensee and R.D. Willig (Amsterdam: Elsevier). 